\title{
PENGEMBANGAN PERANGKAT PEMBELAJARAN BERBASIS INKUIRI TERBIMBING PADA MATERI SENYAWA HIDROKARBON KELAS XI SMAN 1 MAKASSAR
}

\author{
Mardiana $^{1}$, Tabrani Gani ${ }^{2}$, Hasri $^{3}$ \\ ${ }^{1}$ Guru Kimia SMA Negeri 1 Makassar \\ ${ }^{2,3}$ Dosen Program Pascasarjana Universitas Negeri Makassar \\ Email:dian.katle@gmail.com
}

\begin{abstract}
ABSTRAK
Penelitian ini bertujuan untuk: 1) menghasilkan perangkat pembelajaran yang valid, praktis, dan efektif; 2) mengetahui hasil belajar peserta didik kelas XI IPA SMA Negeri 1 Makassar tahun pelajaran 2018/2019 setelah digunakan perangkat pembelajaran berbasis inkuiri terbimbing. Jenis penelitian ini adalah penelitian pengembangan dengan menggunakan model Thiagarajan (Model 4-D) dan uji coba perangkat pembelajaran yang meliputi: RPP, LKPD, dan THB dilaksanakan pada peserta didik kelas XI IPA 4 SMA Negeri 1 Makassar dengan jumlah 34 orang. Hasil uji coba perangkat dalam penelitian ini menunjukan bahwa perangkat pembelajaran yang telah dikembangkan memenuhi kriteria sangat valid, praktis dan efektif digunakan. Kriteria sangat valid diperolah dari nilai rata-rata total keseluruhan aspek dari RPP sebesar 3,86, LKPD sebesar 3,84, dan THB sebesar 3,81. Kriteria praktis diperoleh dari nilai rata-rata total keseluruhan aspek keterlaksanaan perangkat pembelajaran sebesar 1,68 dengan kategori terlaksana seluruhnya . Kriteria efektif dalam penelitian ini dilihat dari peningkatan pretest-posttest. Hal ini didukung oleh hasil perhitungan $\mathrm{N}$ - gain.
\end{abstract}

Kata kunci : Pengembangan Perangkat, Model Inkuiri Terbimbing, Hasil Belajar

\begin{abstract}
The study aims at (1) producing learning device which is valid, practical, and effective, (2) discovering the learning of grade XI at SMAN 1 Makassar of academic year 2018/2019 after the guided inquiri based learning device being used. The type of this study was development research which referred to Thiagarajan (4-d Model) and the test of learning device which covered RPP, LKPD and THB which implemented to grade XI IPA 4 students at SMAN 1 Makassar with the total of 34 students. The result of the study reveals that the learning device developed has met the criteria of very valid, practical and effective to be applied. The very valid criteria are obtained from the average of the total aspects from RPP 3,86, LKPD 3,84 to beHasil uji coba perangkat dalam THB 3,81. The practical criterion is obtained from the average of the total aspects of learning device implementation by 1,68 with entirely implemented category. The effective criteria are based on the improvement of pretest and posttest. Is the supported by the result of N-Gain.
\end{abstract}

Keywords: Development of device, guided inquiry model, learning outcomes.

\section{PENDAHULUAN}

Pendidikan merupakan hak yang harus kita miliki semenjak dari lahir. Melalui pendidikan itulah kita akan banyak tahu tentang wawasan di dunia dalam kehidupan ini. Pendidikan berperan sangat penting oleh karena itu pendidikan harus dilaksanankan dengan sebaik-baiknya sesuai 
tujuan pendidikan nasional yaitu menciptakan manusia yang berkualitas dan berbudi pekerti yang luhur. Untuk mencapai tujuan tersebut pemerintah dalam hal ini Kemendikbud melakukan terobosan baru untuk meningkatkan mutu pendidikan dengan diberlakukannya Kurikulum 2013.

Pengembangan Kurikulum 2013 bertujuan menghasilkan insan Indonesia yang kreatif, inovatif, produktif, afektif melalui penguatan sikap, pengetahuan, dan keterampilan secara terintegrasi. Dalam rangka mewujudkan insan Indonesia yang kreatif, inovatif, produktif dan afektif maka dalam standar proses dinyatakan bahwa proses pembelajaran pada satuan pendidikan diselenggarakan secara, inspiratif, interaktif, menyenangkan, menantang, dan memotivasi peserta didik untuk berpartisipasi aktif, serta memberikan ruang yang cukup bagi prakarsa, kreativitas, dan kemandirian sesuai dengan bakat, minat, dan perkembangan fisik serta psikologis peserta didik (Kemdikbud, 2014)..

Untuk meningkatkan hasil belajar yang lebih optimal guru sebaiknya menggunakan pendekatan, strategi atau model-model pembelajaran yang bervariasi sesuai dengan topik yang dipelajari peserta didik. Beberapa pendekatan, strategi,dan model, pembelajaran yang dikemukakan pakar pendidikan, didasari teori belajar tertentu dan digunakan untuk tujuan tertentu pula. Untuk tujuan pembelajaran yang berbeda digunakan pendekatan, strategi,model, pembelajaran yang berbeda pula. Penggunaan pendekatan, strategi, model pembelajaran hendaknya disesuaikan pula dengan karakteristik mata pelajaran yang diajarkan.

Pelajaran Kimia adalah mata pelajaran yang wajib bagi Sekolah Menengah Atas (SMA) yang banyak menggunakan konsep dari yang sederhana sampai yang lebih kompleks sehingga diperlukan pemahaman yang benar terhadap konsep dasar. Banyak diantara peserta didik yang memaknai konsep yang kompleks adalah konsep yang membingunkan dan menyebabkan peserta didik kurang tertarik terhadap materi pelajaran kimia sehingga peserta didik kesulitan dalam mengaitkan konsep yang satu dengan konsep yang lainnya secara utuh dan benar. Hal tersebut mengakibatkan hasil belajar peserta didik rendah.

Berdasarkan hasil wawancara penulis, peserta didik di kelas XI SMA Negeri 1 Makassar mengalami kesulitan dalam belajar. Hal ini terlihat dari hasil belajar peserta didik pada materi senyawa hidrokarbon hanya sekitar $35 \%$ yang mendapatkan nilai diatas KKM yang ditetapkan guru mata pelajaran kimia, $10 \%$ mendapatkan nilai standar KKM, sedangkan sisanya $55 \%$ berada dalam kategori tidak tuntas. Penyebab rendahnya hasil belajar kimia peserta didik adalah dimungkinkan metode dan model pembelajaran yang berpusat pada guru, sehingga membuat peserta didik kurang aktif dalam belajar dan menyebabkan hasil belajar yang diperoleh peserta didik tidak maksimal. Selain itu kemampuan setiap peserta didik bervariasi dalam menyerap suatu pelajaran juga berpengaruh pada pencapaian hasil belajar kimia, ada yang kemampuan menyerap materi pelajaran sangat cepat, ada yang sedang bahkan ada yang sangat lambat.

Pencapaian hasil belajar maksimal dipengaruhi oleh banyak faktor yaitu proses pembelajaran, kurikulum, tenaga pendidik, sarana dan prasarana serta lingkungan. Tenaga pendidik yaitu guru memegang peranan yang sangat penting dalam pencapaian tujuan pendidikan nasional sehingga guru dituntut untuk memahami bagaimana peserta didik dalam belajar, mampu merancang dan merencanakan proses pembelajaran yang efesien, efektif dan produktif.

Salah satu proses yang mengiringi paradigma tersebut adalah diterapkannya model-model pembelajaran inovatif yang mampu mengembangkan dan menggali pengetahuan peserta didik secara mandiri dan konkrit. Inovasi ini diadopsi dari metode kerja para ilmuwan dalam menemukan suatu pengetahuan baru. Model pembelajaran yang mengorientasikan peserta 
didik agar aktif berpikir, berpusat pada peserta didik menekankan pada pengalamanpengalaman aktif dan dapat menemukan sendiri ide-ide dengan penuh percaya diri dalam pembelajaran sesuai pendekatan saintifik yaitu : model pembelajaran penemuan (Discovery Learning dan inkuiri), pembelajaran berbasis masalah (Problem Based Learning), dan pembelajaran berbasis proyek (Project Based Learning). Setiap model pembelajaran mempunyai kelebihan dan kelemahan, sehingga guru dituntut memilih dan menggunakan model yang sesuai dan tepat dalam pembelajaran (Kemdikbud, 2014).

Penulis tertarik memilih salah satu model pembelajaran yang dapat diterapkan dikelas yaitu model pembelajaran inkuiri terbimbing. Dalam melaksanakan model pembelajaran tersebut diperlukan perangkatperangkat perencanaan dalam proses pembelajaran dalam mengajar yakni: RPP (Rencana Pelaksanaan Pembelajaran, Lembar Kegiatan Peserta Didik (LKPD), dan Tes Hasil Belajar. Hasnawati (2016), mengemukakan bahwa perangkat pembelajaran berbasis inkuiri memudahkan peserta didik dalam proses pembelajaran dan dapat meningkatkan hasil belajar peserta didik.

Perangkat pembelajaran merupakan prasyarat bagi terjadinya interaksi proses mengajar belajar yang optimal karena memberikan kemudahan bagi peserta didik untuk memahami materi dan memudahkan guru untuk mengajarkan suatu materi. Dengan demikian perlu dilakukan perancangan dan pengembangan perangkat pembelajaran yang dapat menekankan pengalaman-pengalaman aktif memecahkan masalah peserta didik dan pembelajaran penemuan yang berpusat pada peserta didik. Ada beberapa model pengembangan sistem dan perangkat pembelajaran antara lain: pengembangan perangkat pembelajaran model Thiagarajan (model 4-D). model PPSI, model Dick \& Carey, dan model Instructional Development Institute (IDI).
Model Kemp, Model pengembangan yang akan digunakan dalam pengembangan perangkat ini adalah model dari Thiagarajan. Alasan dipilihnya model ini karena sangat cocok digunakan pada pengembangan perangkat pembelajaran dan tahapan-tahapan dalam model ini urutan langkahnya sederhana sehingga sangat memudahkan peneliti dalam mengembangkan perangkat dimulai dari tahap pendefinisian sampai tahap penyebaran, urutan-urutan langkah dalam setiap tahap sudah ditentukan, dalam tahap pengembangan melibatkan penilaian ahli, sehingga sebelum dilakukan uji coba di lapangan, perangkat pembelajaran yang menggunakan model tersebut telah mengalami revisi berdasarkan penilaian, saran dan masukan para ahli. Berdasarkan uraian di atas, Peneliti tertarik mengembangkan perangkat pembelajaran melalui penelitian dengan judul "Pengembangan Perangkat Pembelajaran Berbasisi Inkuiri Terbimbing pada Materi Senyawa Hidrokarbon kelas XI SMA Negeri 1 Makassar".

\section{METODE PENELITIAN}

Penelitian ini adalah penelitian pengembangan atau Research and Develoment yang bertujuan untuk mengembangkan dan mendesain perangkat pembelajaran berbasis inkuiri terbimbing pada materi pokok senyawa hidrokarbon untuk meningkatkan hasil belajar peserta didik yang meliputi Rencana Pelaksanaan Pembelajaran (RPP), Lembar Kegiatan Peserta Didik (LKPD) dan Tes Hasil Belajar (THB).

Penelitian ini dilaksanakan di SMA Negeri 1 Makassar dan subjek penelitiannya adalah Peserta Didik kelas XI pada semester ganjil tahun pelajaran 2018/2019 dengan jumlah 35 orang (1 kelas) dari 8 kelas.

Prosedur yang ditempuh dalam penelitian ini di bagi menjadi dua tahap yaitu: tahap persiapan dan tahap pelaksanaan. Kegiatan yang dilakukan pada 
kedua tahap tersebut dapat diuraikan sebagai berikut:

\section{Tahap Persiapan}

Sebelum

pembelajaran kimia melalui model pembelajaran berbasis inkuir terbimbing terlebih dahulu mengurus surat-surat izin penelitian.

\section{Tahap Pelaksanaan}

Pada tahap pelaksanaaan penelitian meliputi beberapa kegiatan antara lain:

a. Mengkaji teori-teori tentang model pembelajaran berbasis inkuiri terbimbing

b. Studi literature model pengembangan 4D

c. Menganalisis kurikulum 2013 untuk memilih standar kompetensi, Kompetensi inti, indikator, dan materi yang di ajarkan dalam penelitian.

d. Mempersiapkan perangkat pembelajaran yang meliputi: RPP, LKPD, dan THB.

e. Perangkat pembelajaran dirancang untuk 4 kali Pertemuan. Kemudian perangkat pembelajaran divalidasi oleh 2 validator untuk menilai validitas isi.

f. Hasil revisi dari validator digunakan peneliti untuk melakukan perbaikan isi terhadap perangkat pembelajaran yang akan digunakan pada pelaksanaan penelitian.

g. Pengambilan sampel dipilih secara acak dengan asumsi bahwa karakteristik peserta didik dari 8 kelas yang ada adalah homogen karena penempatan kelas tidak berdasarkan prestasi.

h. Menentukan waktu pelaksanaan penelitian

i. Melaksanakan kegiatan pembelajaran dengan model perangkat pembelajaran yang telah disusun, peneliti bertindak sebagai guru dan dibantu oleh observer.

Untuk memperoleh informasi yang dibutuhkan dalam penelitian pengembangan perangkat pembelajaran ini, maka dikembangkan instrumen-instrumen penelitian.

\section{Analisis Deskripsi Kuantitatif}

Analisis deskripsi kuantitatif digunakan untuk mendeskripsikan tes hasil belajar kimia. Data yang telah dikumpul diolah dan dianalisis dalam bentuk presentase. Kategori yang digunakan berdasarkan skala penilaian (rating scale) adalah sebagai berikut

\begin{tabular}{|c|l|l|}
\hline No & Rentang Nilai & Kategori \\
\hline 1 & $85-100$ & Sangat Baik \\
\hline 2 & $70-84$ & Baik \\
\hline 3 & $55-64$ & Cukup \\
\hline 4 & $40-54$ & Kurang \\
\hline 5 & $0-39$ & Sangat Kurang \\
\hline
\end{tabular}

\section{Analisis Data Kevalidan Perangkat Pembelajaran}

Adapun kegiatan yang dilakukan dalam proses analisis data kevalidan perangkat pembelajaran yang meliputi Rencana Pelaksanaan Pembelajaran (RPP) Lembar Kegiatan Peserta Didik (LKPD), dan Tes Hasil belajar (THB).

\section{Analisis Data Kepraktisan Perangkat Pembelajaran Berbasis inkuiri terbimbing}

Proses analisis kepraktisan perangkat pembelajaran adalah mencari rata-rata hasil pengamatan dua observer untuk setiap aspek $(\overline{A l})$, setiap kriteria $(\overline{K \iota})$, dan rata-rata $(\bar{X})$, selanjutnya menentukan kategori keterlaksanaan setiap aspek atau keseluruhan aspek keterlaksanaan perangkat pembelajaran (Nurdin, 2007).

\section{Analisis Data Keefektifan Perangkat Pembelajaran}

a. Analisis Data Respon Peserta Didik dan Guru terhadap Pembelajaran

Analisis untuk data hasil angket respon peserta didik dianalisa dengan menentukan persentase jawaban peserta didik untuk setiap aspek respon.

Kegiatan yang dilakukan dalam proses analisis data penilaian kemampuan guru mengelola pembelajaran (Hobri, 2009).

\section{HASIL DAN PEMBAHASAN}

Adapun perangkat pembelajaran yang telah divalidasi dapat dideskripsikan sebagai berikut: 
1) Rencana pelaksanaan pembelajaran (RPP)

\begin{tabular}{llc}
\hline Aspek penilaian & Rata-rata & Keterangan \\
\hline Format & 3,91 & $\mathrm{SV}$ \\
\hline $\begin{array}{l}\text { Materi yang } \\
\text { disajikan }\end{array}$ & 4,00 & $\mathrm{SV}$ \\
\hline Bahasa & 3,75 & $\mathrm{SV}$ \\
\hline Alokasi waktu & 3,75 & $\mathrm{SV}$ \\
\hline Manfaat & 3,75 & $\mathrm{SV}$ \\
\hline $\begin{array}{l}\text { Sarana dan } \\
\text { prasarana }\end{array}$ & 4,00 & $\mathrm{SV}$ \\
\hline Rata-rata total & 3,86 & $\mathrm{SV}$ \\
\hline
\end{tabular}

Sumber: Analisis Hasil validasi RPP

Tabel 4.2 Hasil Validasi Lembar Kegiatan Peserta Didik (LKPD)
Tabel 4.4. Hasil Validasi Pengamatan Keterlaksanaan Perangkat Pembelajaran

\begin{tabular}{lcc}
\hline \multicolumn{1}{c}{ Aspek penilaian } & Rata-rata & Keterangan \\
\hline Aspek tujuan & 3,75 & $\mathrm{SV}$ \\
\hline $\begin{array}{l}\text { Unsur-unsur } \\
\text { cakupan inkuiri } \\
\text { terbimbing }\end{array}$ & 3,80 & $\mathrm{SV}$ \\
\hline Bahasa & 3,83 & $\mathrm{SV}$ \\
\hline Rata-rata total & 3,79 & $\mathrm{SV}$ \\
\hline
\end{tabular}

Sumber: Analisis hasil validasi lembar pengamatan keterlaksanaan perangkat pembelajaran.

Tabel 4.5 Hasil Validasi Lembar Pengamatan Kemampuan Guru Mengelola Pembelajaran Berbasis inkuiri terbimbing Aspek penilaian Rata-rata Keterangan

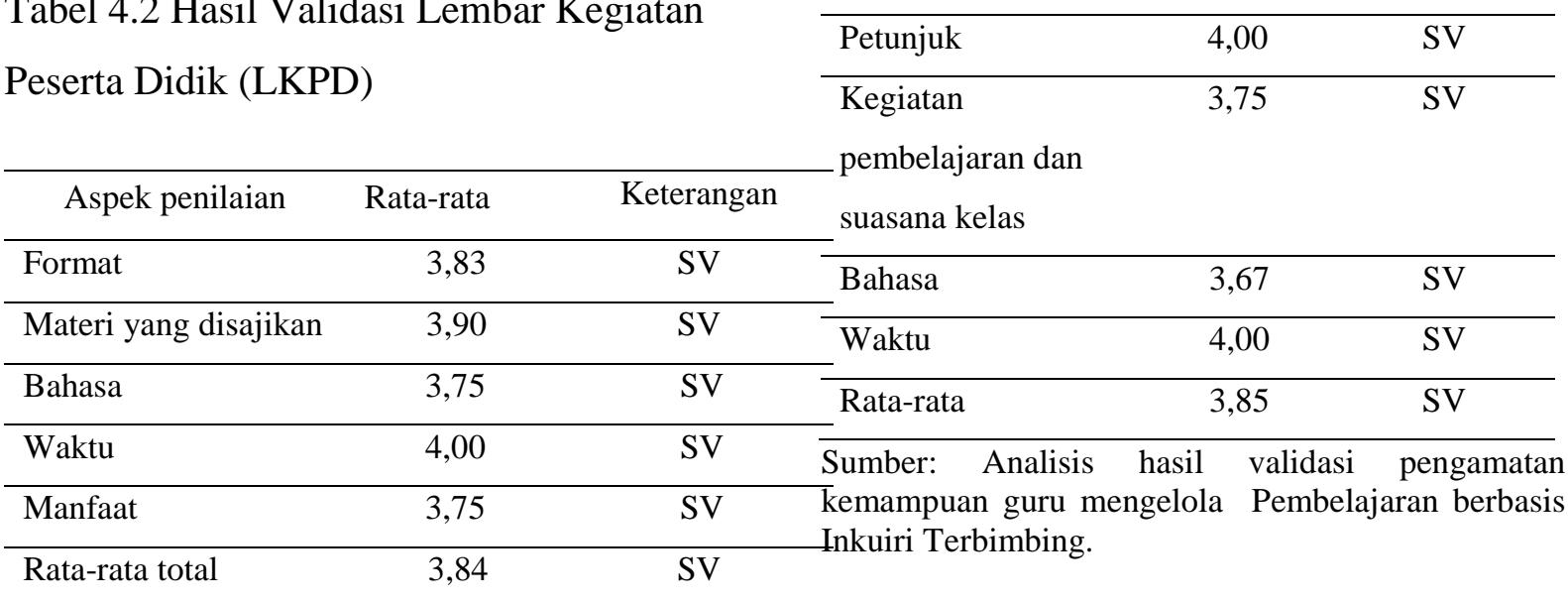

Sumber: Analisis hasil validasi LKPD

Tabel 4.6 Validasi angket respon

Tabel 4.3 Hasil Validasi Tes Hasil Belajar peserta didik

(THB)

Aspek penilaian Rata-rata Keterangan

\begin{tabular}{|c|c|c|c|c|c|}
\hline Bidang Telaah & Rata-rata & Ket & Materi & 3,76 & SV \\
\hline Materi soal & 3,70 & SV & Konstruksi & 4,00 & SV \\
\hline Bahasa & 3,87 & SV & -Bahasa & 3,83 & SV \\
\hline Konstruksi & 3,87 & SV & Rata-rata & 3,83 & SV \\
\hline Rata-rata total & 3,81 & SV & Sumber : A & alidas & Jese \\
\hline
\end{tabular}

Adapun hasil validasi terhadap

Penilaian ahli terhadap respon guru instrumen-instrumen penelitian: dapat dilihat pada Tabel 4.7

1) Hasil validasi instrument kepraktisan

Hasil validasi lembar pengamatan keterlaksanaan perangkat pembelajaran.
Tabel 4.7 Validasi Respon Guru

\begin{tabular}{lcc}
\hline \multicolumn{1}{c}{ Aspek penilaian } & Rata-rata & Keterangan \\
\hline Materi & 3,83 & $\mathrm{SV}$ \\
\hline Konstruksi & 3,50 & $\mathrm{SV}$ \\
\hline
\end{tabular}




\begin{tabular}{lll}
\hline Bahasa & 3,83 & SV \\
\hline Rata-rata & 3,72 & SV
\end{tabular}

Sumber : Hasil analisis Respon Guru

\section{Pembahasan Hasil Penelitian}

1. Nilai kevalidan perangkat pembelajaran Hasil penilaian oleh dua validator ahli yaitu orang yang ahli dalam bidang kimia diperoleh bahwa instrumen yang divalidasi berdasarkan dari data analisis validasi perangkat pembelajaran berada pada kriteria valid. Nilai tersebut berasal dari hasil rata-rata nilai yang diberikan oleh dua ahli dalam menilai instrumen. Instrumen yang telah memenuhi syarat validasi tersebut adalah perangkat pembelajaran RPP, LKPD, instrumen tes hasil belajar, lembar keterlaksanaan perangkat pembelajaran, lembar kemampuan guru mengelola pembelajaran, guru dan angket respon peserta didik. Dari analisis tersebut disimpulkan bahwa pengembangan model pembelajaran berbasis inkuiri terbimbing dapat dipergunakan dalam pelaksanaan proses pembelajaran. Nilai valid dari instrumen tersebut tentunya tidak lepas dari saran dan nasehat para ahli demi kesempurnaan pengembangan model pembelajaran ini serta perangkat pembelajarannya.

1. Kepraktisan perangkat pembelajaran berbasis inkuiri terbimbing

Dari hasil uji pengembangan diperoleh hasil nilai rata-rata keterlaksanaan perangkat pembelajaran di kelas XI IPA 4 adalah 1,68 . Berdasarkan kriteria yang telah diuraikan sebelumnya disimpulkan bahwa nilai rata-rata tersebut berada pada kategori terlaksana seluruhnya. Dengan demikian bahwa implementasi perangkat pembelajaran yang telah dikembangkan melalui instrumen keterlaksanaan perangkat pembelajaran telah memenuhi syarat kepraktisan.

Keefektifan perangkat pembelajaran berbasis inkuiri terbimbing dari hasil penelitian yang telah dilakukan dapat dilihat sebagai berikut:
1) Kemampuan guru mengelola pembelajaran Komponen-komponen yang dijadikan acuan keberhasilan guru dalam mengelola pelaksanaan pembelajaran berbasis inkuiri terbimbing ini dengan melihat pelaksanaan setiap tahap dalam model pembelajaran berbasis inkuiri terbimbing serta suasana yang tercipta dalam proses pembelajaran. Hasil uji pengembangan menunjukkan bahwa pada kelas XI IPA 4 guru mampu mengelola pembelajaran disetiap tahapannya dengan baik karena kemampuan guru mengelola tersebut berada pada kategori sangat tinggi dengan nilai rata-rata 3,64

2) Respon peserta didik terhadap perangkat pembelajaran dan pelaksanaan pembelajaran berbasis inkuiri terbimbing

Angket respon peserta didik ini diberikan agar peserta didik dapat memberi penilaian terhadap perangkat pembelajaran dan pelaksanaan pembelajaran. Respon yang diberikan oleh peserta didik terhadap LKPD, dan cara guru mengajar pada kelas XI MIPA 4 berada pada kategori sangat merespon dengan persentase secara sangat setuju sebesar $17,65 \%$, dan setuju sebesar $82,35 \%$ respon keseluruhan $100 \%$ memberikan respon positif, peserta didik sudah mampu menerima keberadaan model pembelajaran berbasis inkuiri terbimbing yang telah dikembangkan dan menyukai model pembelajaran berbasis inkuiri tersebut karena mampu membantu peserta didik dalam mencapai tujuan pembelajaran

\section{3) Hasil belajar kimia}

Tes hasil belajar kimia yang diberikan pada peserta didik bertujuan untuk mengetahui kemampuan yang dimiliki peserta didik setelah melalui pembelajaran berbasis inkuiri terbimbing yang telah dikembangkan. Pada kelas XI IPA 4 diperoleh bahwa peserta didik yang mampu mencapai nilai diatas KKM yang ditetapkan guru mata pelajaran yaitu 77 sebanyak 29 dari 34 peserta didik dengan persentase 85 $\%$ dan sebanyak 5 dari 34 peserta didik 
memperoleh nilai standar KKM dengan presentase $15 \%$. Berdasarkan hasil analisis data tersebut model pembelajaran berbasis inkuiri terbimbing di kelas XI IPA 4 adalah efektif. Keefektifan pembelajaran berbasis inkuiri terbimbing merupakan gambaran bahwa peserta didik dapat memahami materi senyawa hidrokarbon dengan baik sehingga mampu meningkatkan hasil belajar peserta didik.

\section{SIMPULAN DAN SARAN}

Berdasarkan hasil penelitian yang telah dilakukan, dapat disimpulkan sebagai berikut:

1. Kualitas pengembangan model pembelajaran berbasis inkuiri terbimbing yang meliputi : 1) Rencana Pelaksanaan Pembelajaran (RPP), 2) Lembar Kerja Peserta Didik (LKPD), dan Tes Hasil Belajar, menunjukan bahwa pernagkat pembelajaran ini memenuhi kriteria valid, Praktis dan efektif digunakan.

2. Hasil tes belajar peserta didik sebelum digunakan perangkat pembelajaran berbasis inkuiri terbimbing diperoleh nilai rata-rata 59 dengan kategori sedang sedangkan setelah digunakan perangkat pembelajaran berbasis inkuiri terbimbing mencapai nilai rata-rata 86,47 dengan kategori sangat baik. Hal ini didukung perhitungan N-Gain.

\section{DAFTAR RUJUKAN}

Abidin, Yunus, 2013. Desain Sistem Pembelajaran Dalam Konteks Kurikulum 2013. Bandung : PT Refika Aditama

Anderson, Lorin W., David R. Krathwohl. 2001. Kerangka Landasan Untuk Pembelajaran, Pengajaran dan Asesmen Revisi Taksonomi Bloom.Yogyakarta: Pustaka Pelajar

Annafi, Nurfidianty. 2016. Pengaruh Penerapan LKPD Berbasis Inkuiri Terbimbing di MAN 1 Kota Bima. Journal of EST, Volume 2 Nomor 2
Agustus hal. 98-104. P-ISSN : 24601497, e- ISSN: 2477-3840. Diakses: Online 24 Mei 2017.

Anwar.2013.Tesis. Pengembangan Perangkat Pembelajaran Fisika berbasis Inkuiri Terbimbing untuk Meningkatkan Aktivitas dan Hasil Belajar Peserta didik SMP Negeri 2 Pitu Riase Kabupaten Sidrap.Tidak diterbitkan.Makassar.

Arsyad, Azhar. 2005. Media Pembelajaran. Jakarta: Raja Grafindo Persada

Asrori, Mohammad. 2009. Psikologi

Pembelajaran. Bandung: CV. Wacana Prima

Borg, W.R. \& Gall, M. D. 1983. Educational

Research. Fourt edition. New York: Longman Inc.

Bilgin, Ibrahim. 2009. The effects of guide inquiry instruction incorporating a cooperative learning approach on university students' achievement of acid and bases concepts and attitude toward guided inquiry instruction. Scientific Research and Essay Vol. 4 (10), pp. 1038-1046, ISSN 19922248@ 2009 Academic Journals. Mustafa Kemal University Hatay Turkey. Diakses : online 1 september 2017.

Budiastra, A.A., 2015. The development of measurement tools for senior high school students' critical thinking skills in chemistry. Int. J. Adv. Res. Manag. Soc. Sci. 4, 108-121

Depdiknas. 2008. Panduan Pengembangan Bahan Ajar. Jakarta: Departemen Pendidikan Nasional Direktorat Pendidikan Dasar dan Menengah.

Duron, Robert., Barbara Limbach and Wendy Waugh. 2006. International Journal of Teaching and Learning in Higher Education. Volume 17, Number 2, 160-166 ISSN 18129129, http://www.isetl.org/ijtlhe/. Husson College \& Chadron State College. Diakses 19 Agustus 2017. 
Fatmaryanti, S.D., Suparmi., Sarwanto., Ashadi. 2015. Implementation Of Guided Inquiry In Physics Learning At Purworejo's Senior High School. International Conference on Mathematics, Science, and Education (ICMSE 2015. Doctorate Program on Science Education, School of Postgraduate, Sebelas Maret University, Surakarta, Indonesia. Diakses 22 Juni 2017

Gudeva, L.K., Dimova, V., Daskalovska, N., Trajkova, F., 2012. Designing Descriptors of Learning Outcomes for Higher Education Qualification. Procedia - Soc. Behav. Sci. 46, 1306-1311.

Hake. 1999. Interactive-engangement vs traditional methods: a six-thosandstudent survey of mechanics test data for intruductory physics courses. American Journal of Physics, 66(1), 64-74

Handayani., L, Sarwi., Praptiwi, L. 2012. Efektivitas Model Pembelajaran Eksperimen Inkuiri Terbimbing Berbantuan My Own Dictionary untuk Meningkatkan Penguasaan Konsep dan untuk Kerja Siswa SMP RSBI. Journal Education. 1 (2).

Hanson, David .M. 2006. Instructor's Guided to Process- Oriented Guided Inquiry Learning. Lisle, IL: Pacific Crest.

Hasnawati. 2016.Tesis. Penngembangan Perangkat Pembelajaran Fisika berbasis Inkuiri Terbimbing Terhadap Pencapaian Hasil Belajar Peserta Didik Kelas X SMA Negeri 1 Polut Kabupaten Takalar. Makassar: Universitas Negeri Makassar.

Hobri. 2009. Metodologi Penelitian pengembangan. Jakarta : Proyek DIA

BERMUTU Program Pendidikan Matematika FKIP Universitas Jember.

Kai, H.W., Krajcik, J.S. 2006. Inscriptional practices in two inquiry-based classrooms: A case study of seventh graders' use of data tables and graphs. Journal of Research in Science Teaching, 43 (1): 63-95

Karsli, F., Calik, M., 2012. Can Freshman Science Student Teachers' Alternative Conceptions of'Electrochemical Cells' Be Fully Diminished?. Asian J. Chem. 24, 485-491. Department of Science Education, Giresun University, Turkey

Kemdikbud.2014. Permendikbud No.59

Tahun

2014 tentang Kurikulum 2013

Sekolah Menengah Atas/ Madrasah

Aliyah. Jakarta : Puskurbuk

Kuhlthau, C.C., Maniotes,L.K, dan Caspari, A. K. 2008. Guided Inquiry: Learning in the $21^{\text {th }}$ century. London: Libraries Unlimite. Diakses online : 26 Juli 2017

Kurniawan, D, A. 2013. Metode Inkuiri Terbimbing dalam Pembuatan Media Pembelajaran Biologi untuk Meningkatkan Pemahaman Konsep dan Kreativitas Siswa SMP. Jurnal Pendidikan IPA Indonesia. 2. (1). Diakses online: 4 Juni 2017

Matthew, B.M. \& Kenneth,I.O. 2013. A Study on The Effects of Guided Inquiry Teaching Method on Students Achievement in Logic. International Research. 2(1): 134140.

McArdle WD, Katch FI, Katch VL. 2010. Exercise physiology : nutrition, energy, and human performance. Edisi ke 7. Philadelphia: Lippincott William \& Wilkins

Nurdin. 2007. Model Pembelajaran Matematika Untuk Menumbuhkan Kemampuan Metakognitif Untuk Menguasai Bahan Ajar. Surabaya: Unesa.

Nurhadi dkk. 2004.Pembelajaran Kontekstual .Malang: Universitas Negeri Malang.

Permana, I. 2009. Memahami Kimia 2: Untuk SMA/MA Kelas XI Semester 1 
dan 2 Program Ilmu Pengetahuan Alam. Jakarta: Depdiknas

Prastowo, A. 2011. Panduan Kreatif Membuat Bahan Ajar Inovatif: Menciptakan Metode Pembelajaran yang Menarik dan Menyenangkan. Yogyakarta: Diva Press.

Purwanto. 2013. Evaluasi Hasil Belajar.Yogyakarta: Pustaka Pelajar.

Putra, Sittiatava Rizema. 2013. Desain Belajar Mengajar Kreatif Berbasis Sains. Jogyakarta: DIVA Press.

Rizalini, Rina. 2017. Pengembangan Lembar Kegiatan Peserta Didik Kimia Berbasis Inkuiri Terbimbing untuk Kelas XI IPA SMA/ MA. Tesis: Program Pascasarjana Universitas Negeri Yogyakarta. Diterbitkan Diakses 2 september 2017.

Rusman. 2011. Seri Manajemen Sekolah Bermutu Model-Model Pembelajaran Mengembangkan profesionalisme Guru. PT. Raja Grafindo Persada. Jakarta.

Sani, Ridwan Abdullah. 2016. Inovasi Pembelajaran. Jakarta: Bumi Aksara

Sanjaya, W. 2008. Strategi Pembelajaran Berorientasi Standar Proses Pendidikan. Jakarta: Kencana Prenada Media.

Sanjaya, W. 2009. Penelitian Tindakan Kelas. Jakarta: Kencana Premada Media Group.

Silver, C.E.H., Duncan, R. G., Chinn, C. A., 2007. Scafolding and achievement in Problem-Based and Inquiry Learning: A Responses to Kirscher, Sweller, and Clark (2006). Educational Psychologist 42(2), 99107

Soegiranto,M.A. 2010. Acuan Penilaian Bahan Ajar dalam Bentuk Modul.Pokja Kurikulum dan Supervisi Pusat Pengembangan Madrasah Kementerian Agama Provinsi Nusa Tenggara Timur.

Sudjana. 2004. Penilaian Hasil Proses Belajar Mengajar. Bandung: PT. Remaja Rosdikarya.
Sugiyono. 2010. Metode Penelitian Pendidikan Pendekatan Kuantitatif, Kualitatif dan $R \& D$. Bandung Alfabeta.

Suprijono, A., 2009. Cooperative learning: teori \& aplikasi PAIKEM. Pustaka Pelajar.

Suyanti, Retno Dwi. 2010. Strategi Pembelajaran Kimia.Yogyakarta: Graha Ilmu.

Suyanto, Eko dan Sartinem. 2009. Pengembangan Contoh Lembar Kerja Fisika Siswa dengan Latar Penuntasan Bekal Awal Ajar Tugas Studi Pustaka dan Keterampilan Proses untuk SMA Negeri 3 Bandar Lampung. Prosiding Seminar Nasional Pendidikan 2009. Bandar Lampung: Unila.

Syah, Muhubbin. 2004. Psikologi Pendidikan dengan Pendekatan Baru. Bandung: Remaja Rosdakarya.

Thiagarajan, S. 1974 Instructional Development For Training Teacher of Expectional Children.Indiana University.

Trianto. 2011. Model pembelajaran Terpadu dalam Teori dan Praktek. Jakarta: Prestasi Pustaka.

Trianto. 2013. Mendesain Model Pembelajaran Inovatif-Progresif. Jakarta: Kencana.

Wahyuningsih, F., Sulistyo. S, \& Sri Mulyani. 2014. Pengembangan LKS Berbasis Inkuiri Terbimbing pada Materi Pokok Hidrolisis Garam untuk SMA/MA. Jurnal Paedagogia, Vol 17 No.1. ISSN 1026-4109. Universitas Sebelas Maret. Diakses pada tanggal 4 April 2017.

Widiyanto, Ibnu .2008. Pointers: Metodologi Penelitian. Semarang : BP Undip.

Widjajanti, E. 2008. Kualitas Lembar Kerja Siswa. Makalah yang disampaiakan dalam Kegiatan Pengabdian pada Masyarakat dengan Judul" Penyusunan LKS Mata Pelajaran Kimia. Berdasarkan Kurikulum 
Tingkat Satuan Pendidikan Bagi Guru SMK/MAK'. Jurusan Pendidikan Kimia. FMIPA UNY. Diakses: 4 Mei 2017

Widjajanti, E. 2008. Kualitas Lembar Kerja Siswa. Makalah yang disampaiakan dalam Kegiatan Pengabdian pada Masyarakat dengan Judul" Penyusunan LKS Mata Pelajaran Kimia. Berdasarkan Kurikulum Tingkat Satuan Pendidikan Bagi Guru SMK/MAK'. Jurusan Pendidikan Kimia. FMIPA UNY. Diakses: 4 Mei 2017

Zaini, Muhammad. 2016. Guided Inquiry Based Learning on the Concept of Ecosystem Toward Learning Outcomes and Critical Thinking Skills of High School Students. IOSR Journal of Research \& Method in Education (IOSR-JRME) e-ISSN: 2320-7388,p-ISSN: $\quad 2320-737 X$ Volume 6, Issue 6 Ver. VIII (Nov. Dec. 2016), PP 50-55 www.iosrjournals.org. Diakses : 29 Agustus 2017 